\title{
Legal Abortion Worldwide: Incidence and Recent Trends
}

\author{
By Gilda Sedgh, \\ Stanley K. \\ Henshaw, \\ Susheela Singh, \\ Akinrinola Bankole \\ and Joanna \\ Drescher
}

Gilda Sedgh is senior research associate,

Stanley K. Henshaw is senior fellow,

Susheela Singh is vice president of research,

Akinrinola Bankole is

director of interna-

tional research and at

the time of writing

Joanna Drescher was

research associate-all

at the Guttmacher

Institute, New York.
CONTEXT: Information on abortion levels and trends can inform research and policies affecting maternal and reproductive health, but the incidence of legal abortion has not been assessed in nearly a decade.

METHODS: Statistics on legal abortions in 2003 were compiled for 60 countries in which the procedure is broadly legal, and trends were assessed where possible. Data sources included published and unpublished reports from official national reporting systems, questionnaires sent to government agencies and nationally representative population surveys. The completeness of country estimates was assessed by officials involved in data collection and by in-country and regional experts.

RESULTS: In recent years, more countries experienced a decline in legal abortion rates than an increase, among those for which statistics are complete and trend data are available. The most dramatic declines were in Eastern Europe and Central Asia, where rates remained among the highest in the world. The highest estimated levels were in Armenia, Azerbaijan and Georgia, where surveys indicate that women will have close to three abortions each on average in their lifetimes. The U.S. abortion rate dropped by $8 \%$ between 1996 and 2003, but remained higher than rates in many Northern and Western European countries. Rates increased in the Netherlands and New Zealand. The official abortion rate declined by $21 \%$ over seven years in China, which accounted for a third of the world's legal abortions in 1996. Trends in the abortion rate differed across age-groups in some countries.

CONCLUSIONS: The abortion rate varies widely across the countries in which legal abortion is generally available and has declined in many countries since the mid-1990s.

International Family Planning Perspectives, 2007, 33(3):106-116
In recent decades, abortion has received considerable attention, and its legality and availability have often generated controversy. Even in countries where abortion is not a contentious issue, contraception is usually a less expensive and less taxing means of avoiding unintended births. Accurate information on abortion levels and trends can help donors, policymakers and program planners assess the extent to which women experience unintended pregnancies, and can facilitate the development of policies and programs to respond to unmet need for effective contraceptive services. Accurate measures of abortion can also inform the public discourse by providing impartial, empirical evidence of abortion prevalence.

The last assessment of abortion levels in countries where legal abortion is generally available* was conducted nearly a decade ago. ${ }^{1}$ According to that study, up to the mid1990s, legal abortion rates had been falling in many parts

*Countries are included in this category if abortion is allowed for social or economic reasons or without specification as to reason. A few countries with more restrictive formal laws are included because sources indicate that legal abortion is broadly available: Australia, Hong Kong, Israel, New Zealand and Spain, where abortion is permitted to protect the woman's mental health, and South Korea, where it is permitted to protect her physical health.

tDependent territories with separate abortion statistics or legislation are treated as countries. of the world, either as contraceptive prevalence was increasing or as contraceptives were being used more effectively. The investigators speculated that although the legalization of abortion may initially result in an increase in the number of reported abortions in countries where desired fertility is low, abortion rates will eventually decline as access to family planning education and contraceptive services increases. ${ }^{2}$ Updated information on abortion incidence is needed to assess recent trends and current patterns in induced abortion across countries and regions and in different age-groups, and to document abortion incidence in countries in which legal abortion has recently become available.

In this article, we present statistics on the level of induced abortion in 60 countries and territories in which legal abortion was generally available in 2003. ${ }^{\dagger}$ We assess the completeness of the available abortion data, and wherever statistics of comparable quality are available for 1996 (the most recent year for which similar statistics have been published ${ }^{1}$ ), we report trends in abortion incidence. In addition, for countries with sufficiently complete data on legal abortion, we provide recent age-specific abortion rates, which can help identify groups of women who are experiencing the greatest difficulties in preventing unintended pregnancy. 


\section{METHODS}

\section{Data Collection}

We employed methods similar to those used in the last review of the incidence of abortion worldwide. ${ }^{l}$ For each country or territory with a population of at least one million in which legal abortion was generally available in 2003, we sought data on the total and age-specific numbers of abortions. Several sources of data were used: published abortion data from national statistical offices or relevant government agencies; for countries that lacked such data, responses to a standardized questionnaire or formal inquiry that we sent to appropriate government agencies, sometimes with the help of local contacts; for a few countries, abortion data from the Council of Europe or the European Region of the World Health Organization; 3,4 and for countries whose official statistics were deemed incomplete or unavailable, abortion estimates from nationally representative population surveys.

Most of the statistics presented here are based on official reports of the numbers of induced abortions performed according to the laws of the countries. However, the available abortion statistics are not always complete. For example, providers do not always report all abortions they perform, even if legally required to do so. In some countries, only abortions performed at public facilities are reported, whereas large proportions of abortions are performed at private facilities. In addition, medication abortions or early surgical procedures may be underreported in some countries.

We asked local experts to assess the extent to which the reported statistics represented all legal abortions that had been performed. These experts included researchers, officials from government agencies involved in abortion data collection, and program administrators and providers who were familiar with abortion reporting practices. We also ensured that published statistics did not include spontaneous abortions, and confirmed that they included menstrual regulations (or "mini-abortions") where these are recorded separately. Furthermore, we drew upon any available studies that assessed the quality of a country's abortion data. All of this information was used to classify countries according to whether their abortion data are complete (defined as including at least $80 \%$ of all legal abortions) or incomplete, or whether the completeness of the available data is in doubt.

We obtained data for 60 of the 66 countries eligible for inclusion in this study. ${ }^{*}$ For 33 of these countries, published or local sources indicated that the statistics included at least $80 \%$ of the actual number of legal abortions performed in that year. For 16 countries, local experts determined that the statistics were incomplete; for 11, we were unable to obtain a reliable assessment about the completeness of reporting. Survey-based estimates, while at times superior to government reporting systems, were always assumed to be incomplete because some women do not report their abortions, particularly in face-to-face interviews, 5,6 and surveys are subject to sampling error and random variation.
For all but four of the 33 countries considered to have complete counts, the data were government statistics. For Puerto Rico ${ }^{7}$ and the United States, ${ }^{8}$ data collected through surveys of all providers were used; the U.S. estimate for 2000 was projected to 2003. ${ }^{9}$ For Australia, we used a published estimate based on insurance claims and hospital statistics. ${ }^{10}$ For Switzerland, we used data compiled by a private organization using reports from local government offices. ${ }^{11}$

Government statistics were available for 24 of the 27 countries with estimates that are incomplete or of unknown completeness. For South Korea, Turkey and Turkmenistan, only survey-based estimates were available. The survey in South Korea was administered to married women only, and the survey in Turkey was administered to ever-married women only. In 11 countries where both official statistics and nationally representative survey data were available, both sets of findings are shown. In all but one of these countries, survey estimates were based on women's reports of their induced abortions obtained in the one-, three- or fiveyear period prior to the survey. The abortion estimate for India is derived from a facility-based survey. In eight countries with incomplete reporting or reporting of uncertain completeness (China, Georgia, Hong Kong, India, Japan, Romania, Turkey and Vietnam), abortion estimates from the same data source are available for 1996, and these are presented as well.

We also obtained estimates of the population of women aged 15-44 in five-year age-groups and numbers of live births to calculate abortion rates and ratios for 2003. When available, we used data from country statistical offices. For countries where population estimates were not available, we used estimates published by the Council of Europe or the United Nations. We interpolated where necessary to obtain midyear population estimates.

\section{Analysis}

We calculated age-specific abortion rates (the number of abortions per 1,000 women in each five-year age-group), the general abortion rate (the number of abortions annually per 1,000 women aged 15-44), the total abortion rate (the number of abortions a woman would be expected to have over a lifetime at current age-specific rates) and the abortion ratio (the number of abortions per 100 live births) for each country. When age-specific abortion data were not available, the total abortion rate was estimated from the general abortion rate. ${ }^{\dagger}$ Some fertility surveys report only the total abortion rate; in these cases, we estimated the general abortion rate and number of abortions from the total abortion rate. Where complete and comparable abortion statistics were available for two time periods, we present the average annual change in the general abortion rate dur-

*Official estimates for Austria and Greece represent a negligible proportion of all abortions and are not included. We were unable to obtain abortion statistics for Bosnia and Herzegovina, North Korea, Taiwan or Zambia.

†To estimate the total abortion rate, we divided the general abortion rate for women aged $15-44$ by 1,000 , and multiplied the result by 30 (the number of years in this range). 


\begin{tabular}{|c|c|c|c|c|c|c|c|}
\hline \multirow[t]{2}{*}{ Country } & \multicolumn{2}{|l|}{ No.* } & \multicolumn{3}{|l|}{ Rate† } & \multirow[b]{2}{*}{$\begin{array}{l}\text { Ratio, } \neq \\
2003\end{array}$} & \multirow{2}{*}{$\begin{array}{l}\text { Total } \\
\text { abortion } \\
\text { rate, } \S \\
2003\end{array}$} \\
\hline & 2003 & 1996 & 2003 & 1996 & $\begin{array}{l}\text { Average } \\
\text { annual \% } \\
\text { change }\end{array}$ & & \\
\hline \multicolumn{8}{|l|}{ Eastern Europe } \\
\hline Belarus** & 80,200 & $\mathrm{u}$ & 35 & $\mathrm{u}$ & u & 91 & $1.1+t$ \\
\hline Bulgaria & 34,700 & 89,000 & 22 & 51 & -11.7 & 52 & $0.6+t$ \\
\hline Czech Republic & 27,100 & 46,500 & 13 & 21 & -6.9 & 29 & 0.4 \\
\hline Hungary & 53,800 & 76,600 & 26 & 35 & -4.2 & 57 & 0.7 \\
\hline Russian Federation & $1,504,000$ & $2,284,600$ & 45 & 69 & -6.0 & 104 & 1.3 \\
\hline Slovakia & 16,200 & 25,200 & 13 & 20 & -6.1 & 31 & $0.4+\dagger$ \\
\hline \multicolumn{8}{|l|}{ Northern Europe } \\
\hline Denmark & 15,600 & 18,100 & 15 & 16 & -1.6 & 24 & 0.4 \\
\hline England and Walesł‡ & $\neq 181,600$ & 167,900 & 17 & 16 & 0.9 & 29 & 0.5 \\
\hline Estonia & 10,600 & 16,900 & 36 & 56 & -6.1 & 82 & 1.1 \\
\hline Finland & 10,700 & 10,400 & 11 & 10 & 1.1 & 19 & 0.3 \\
\hline Latvia & 19,000 & 23,100 & 29 & 44 & -6.0 & 69 & 0.9 \\
\hline Lithuania & 11,500 & 27,800 & 15 & 34 & -11.0 & 38 & 0.5 \\
\hline Norway & 13,800 & 14,300 & 15 & 16 & -0.5 & 25 & 0.5 \\
\hline Scotland§§ & 12,600 & 12,300 & 12 & 11 & 0.5 & 23 & 0.4 \\
\hline Sweden & 34,400 & 32,100 & 20 & 19 & 1.1 & 34 & 0.6 \\
\hline \multicolumn{8}{|l|}{ Southern Europe } \\
\hline Italy & 132,800 & $\mathrm{u}$ & 11 & $\mathrm{u}$ & u & 25 & 0.3 \\
\hline Slovenia & 6,900 & 10,400 & 16 & 23 & -5.2 & 40 & 0.5 \\
\hline \multicolumn{8}{|l|}{ Western Europe } \\
\hline Belgium*十 & 16,200 & 14,800 & 8 & 7 & 1.7 & 14 & 0.2 \\
\hline France & 208,800 & 189,800 & 17 & 15 & 1.6 & 26 & $0.5+t$ \\
\hline Germany* $\dagger$ & 129,300 & 130,900 & 8 & 8 & 0.2 & 18 & 0.2 \\
\hline 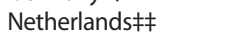 & 28,800 & 22,400 & 9 & 7 & 4.0 & 14 & 0.3 \\
\hline Switzerland & 10,500 & $\mathrm{u}$ & 7 & u & u & 15 & $0.2+t$ \\
\hline \multicolumn{8}{|l|}{ North America } \\
\hline Canada* $\neq$ & 104,200 & 111,800 & 15 & 16 & -0.3 & 31 & 0.5 \\
\hline United States*§ & $1,287,000$ & $1,360,200$ & 21 & 22 & -1.2 & 31 & 0.6 \\
\hline \multicolumn{8}{|l|}{ Oceania } \\
\hline Australia & 84,500 & 89,100 & 20 & 22 & -1.3 & 34 & $0.6+t$ \\
\hline New Zealand & 18,500 & 14,800 & 21 & 17 & 2.8 & 33 & 0.7 \\
\hline \multicolumn{8}{|c|}{ South/Southeast Asia } \\
\hline Nepalt** & 33,100 & u & 5 & u & u & 4 & $0.2+t$ \\
\hline Singapore & 12,300 & 14,400 & 15 & 16 & -0.9 & 31 & $0.4+t$ \\
\hline \multicolumn{8}{|l|}{ Western Asia } \\
\hline \multicolumn{8}{|l|}{ Caribbean } \\
\hline Cubat§ & 151,500 & 209,900 & 57 & 78 & -3.8 & 109 & $1.7+t$ \\
\hline Puerto Rico¥** & 15,600 & 19,200 & 18 & 23 & -2.2 & 28 & $0.5+t$ \\
\hline \multicolumn{8}{|l|}{ Africa } \\
\hline South Africa & 70,100 & u & 6 & u & u & 6 & $0.2+t$ \\
\hline Tunisiał† & 16,000 & 19,000 & 7 & 9 & -6.1 & 9 & $0.2+t$ \\
\hline
\end{tabular}

*Rounded to the nearest 100 . †Abortions per 1,000 women aged 15-44. ¥Abortions per 100 live births. §The number of abortions that the average woman would have during her reproductive lifetime, given present agespecific abortion rates. * ${ }^{*}$ May include spontaneous abortions. ++ Estimated by dividing the general abortion rate by 1,000 and multiplying by 30 . ¥¥Residents only. $\S \S$ Includes abortions residents obtained in England or Wales. *Includes abortions residents obtained in the Netherlands. *Includes abortions residents obtained in selected U.S. states. *§Estimates are provisional and may change as more data become available. †*Abortions from March 2005 to February 2006. †AAbortion applications approved, as reported to the Central Bureau of Statistics. †\$Estimates are for 1996 and 2004. ₹*Estimates are for 1991 and 2001. \#+Estimates are for 1996 and 2000. Note: $\mathrm{u}=$ unavailable. on abortions obtained by these women and the population aged 40-44.

\section{RESULTS}

\section{Countries with Complete Statistics}

- Overall levels and trends. Of the 33 countries with relatively complete counts, ${ }^{*}$ the numbers of legal abortions were greatest in the Russian Federation and the United Statesmore than one million each in 2003 (Table 1). At the other extreme, eight countries reported fewer than 15,000 abortions in 2003. The number of legal abortions per 1,000 women of reproductive age was highest in Cuba (57) and the Russian Federation (45). The legal abortion rate was lowest in Nepal (five) and South Africa (six), both countries where abortion was recently legalized and unreported, illegal abortions are still common. Other than these two countries, abortion rates were lowest in Belgium, Germany, Switzerland and Tunisia (7-8), where reported rates more accurately reflect the level of abortion because illegal abortions are rare.

Cuba and the Russian Federation, which had the highest official abortion rates, also had the highest number of abortions per 100 live births: Their abortion ratios of 109 and 104, respectively, reveal that more abortions than births occur annually. Aside from Nepal and South Africa, Tunisia had the lowest abortion ratio (nine).

In four countries with relatively complete data-Belarus, Cuba, Estonia and the Russian Federation-the total abortion rate was greater than 1.0, indicating that at current rates, the average woman would have more than one abortion in her lifetime. In the countries with the lowest total abortion rates, 0.2 abortions occur per woman over a lifetime, or one abortion for every five women.

Since 1996, abortion rates declined by at least $2 \%$ per year in 12 of the 28 countries with complete abortion counts and trend data, and rates increased by this much in two countries. Abortion rates were relatively stable in the remaining countries.

-Eastern Europe. Many of the most dramatic declines in abortion incidence between 1996 and 2003 occurred in Eastern Europe, which includes several countries of the former Soviet Union. These countries had some of the highest abortion rates in 1996, and despite significant declines, they continued to have the highest rates in 2003. The average annual decreases in abortion rate ranged from $4 \%$ in Hungary to $12 \%$ in Bulgaria, which represent net declines of $26 \%$ and $58 \%$, respectively. ${ }^{\dagger}$ The declines in this region represent a continuation of a trend that began in the early 1990s. ${ }^{12}$ Although in-country informants estimated that the official statistics are complete, an increasing number of abortions are paid for privately, and these procedures

*Since 1996, five countries have been reclassified as having complete statistics: Lithuania and Russia, because of new information about the accuracy of the data; France, because of a new, more complete data source; and Italy and South Africa, because of improvements in data collection. Additionally, Nepal is now included because abortion was legalized in 2003.

tNet changes were calculated using unrounded abortion rates and so may differ from calculations based on the rounded rates listed in tables. 
are often not reported. ${ }^{13,14}$ The magnitude of the downward trend may therefore be exaggerated by measures based on official statistics in some of these countries. In most countries in this region, the declines coincided with increases in access to and use of modern methods of contraception in place of traditional methods (which have played a prominent role in family planning in these countries) and nonuse. ${ }^{14-16}$

- Northern, Western and Southern Europe. The 2003 abortion rates in the Northern European countries of Denmark, England and Wales, Finland, Norway, Scotland and Sweden changed little compared with rates in 1996, and ranged from 11 to 20 per 1,000 women. The rates were also low in Western Europe, where they ranged from seven (in Switzerland) to 17 (in France).

The abortion rate increased in the Netherlands by $31 \%$ over seven years, partly because of a growing demand for terminations from women in ethnic minority groups residing in the country. ${ }^{17,18}$ Abortion rates otherwise changed minimally in Western Europe between 1996 and 2003. Medication abortion (using mifepristone) was introduced in a number of European countries before or during this period. It was approved in France in 1988, in Great Britain and Sweden in 1992, and in Belgium in 1999; mifepristone was registered and approved in Denmark, Finland, the Netherlands and Germany in 1999 in accordance with the European Union's principle of mutual recognition. Regulatory mechanisms and insurance reimbursement policies for medication abortion have affected the availability of this procedure to varying degrees in all of these countries. ${ }^{19}$ The steady abortion rates in these countries (except the Netherlands) suggest that medication abortion is substituting for surgical abortion at the national level, and that its availability has not resulted in increased incidence of abortion.

Italy's abortion rate of 11 per 1,000 women was apparently unchanged since 1996 (not shown), but the more recent statistical report indicated that the 1996 count was less complete than the 2003 count. ${ }^{20}$ A separate report indicated that abortions decreased among Italian-born women and increased among immigrants in the late 1990s. ${ }^{21}$

- Oceania and North America. The abortion rate decreased slightly in Australia, to 20 per 1,000 women in 2003. However, it increased by nearly $3 \%$ per year (21\% over seven years) in New Zealand, where the rate declined slightly among women of European descent and increased substantially among women of Asian ethnicity. ${ }^{22}$

The abortion rate in the United States declined by $8 \%$ between 1996 and 2003 to 21 per 1,000 women, but remained higher, and in some cases substantially higher, than the rates in many Northern and Western European countries. However, within the United States, abortion levels differed widely by racial or ethnic group. In 2000, the abortion rate was 12 among white women, 31 among Hispanic women and 57 among black women. ${ }^{12}$

- Developing countries. Legal abortion is generally available in relatively few developing countries or territories, and abortion rates vary widely across them. Cuba had one of the highest rates among countries with complete counts in 2003, though its rate has fallen in the past decade (from 78 to 57 per 1,000 women). It has been reported that the family planning program in Cuba has sought to expand the range of methods available beyond the IUD, which has long been the predominant method, and to improve the quality of family planning services. ${ }^{23}$

In contrast, the abortion rate in Puerto Rico was 18 in 2001, having declined from 23 in 1991. ${ }^{7}$ Surveys of women indicate that the use of modern contraceptives in this territory was widespread and continued to increase over this period. ${ }^{24,25}$ The rate was also low in Tunisia, where government investment in family planning has been long-standing. ${ }^{26}$

The legal abortion rate in South Africa was very low (six per 1,000 women), but many abortions are performed outside the legal sector, despite liberalization of the abortion law in $1997 .{ }^{27}$ The estimated rate of unsafe (primarily illegal) abortions for the Southern Africa region is nearly three times this legal abortion rate, ${ }^{28}$ and South Africa makes up $90 \%$ of the region's population. A review of abortion service provision in 2000 found that access to services remained limited and inequitable, and that many hospitalbased providers were openly hostile toward women seeking abortions. ${ }^{29}$ Available evidence does not allow us to determine recent trends or the total level of abortion (legal and illegal) in South Africa. As services become more available, the rate of legal abortion will likely increase and the use of illegal abortions will likely decline.

Legal abortion became available in Nepal in March 2004, and the count in Table 1 represents legal procedures in 2005-2006. Access to legal abortion has so far been constrained by the cost of services, uneven access to approved health facilities and lack of awareness about the law. As in South Africa, this count probably represents a small portion of the total number of abortions that are occurring, and the reported abortion rate will likely increase as more abortions are performed in the legal sector.

\section{Countries with Incomplete Statistics}

In the 27 countries for which reporting is incomplete or the level of completeness is unknown, ${ }^{*}$ the true incidence of abortion is likely higher than the reported incidence. Very low reported abortion rates are often not meaningful, since they may represent severe underestimations.

-Eastern Europe and Central and Western Asia. Survey-based estimates as well as government statistics are available for Armenia, Azerbaijan, Georgia, Kazakhstan, Kyrgyzstan, Moldova, Romania, Ukraine and Uzbekistan (Table 2, page 110). The contrast between the abortion counts from the two sources in all countries but Romania indicates that abortions are highly underreported in the official statistics. For example, in Azerbaijan, six abortions per 1,000 women aged

*Zambia was included in the prior round of estimates but was excluded here because of a lack of recent information; Northern Ireland has been added. Abortion reporting in Kazakhstan was considered complete in 1996, but is now classified as incomplete because a nationally representative survey revealed that abortion levels exceed the official count. The former Yugoslavia is now Serbia and Montenegro. 


\begin{tabular}{|c|c|c|c|c|c|c|c|c|c|c|c|}
\hline Country & Year & No.* & Rate† & Ratioł & $\begin{array}{l}\text { Total } \\
\text { abortion } \\
\text { rate§ }\end{array}$ & Country & Year & No.* & Rate† & Ratioł & $\begin{array}{l}\text { Total } \\
\text { abortion } \\
\text { rate§ }\end{array}$ \\
\hline $\begin{array}{l}\text { Eastern Europe } \\
\text { Moldova }\end{array}$ & $\begin{array}{l}2003 \\
2005+\dagger\end{array}$ & $\begin{array}{l}13,600 \\
30,600\end{array}$ & $\begin{array}{l}16 \\
35\end{array}$ & $\begin{array}{l}37 \\
62\end{array}$ & $\begin{array}{l}0.5^{* *} \\
1.1^{* *}\end{array}$ & $\begin{array}{l}\text { East Asia } \\
\text { China }\end{array}$ & $\begin{array}{l}2003 \\
1996\end{array}$ & $\begin{array}{l}7,215,400 \\
8,834,200\end{array}$ & $\begin{array}{l}23 \\
29\end{array}$ & $\begin{array}{l}41 \\
44\end{array}$ & $\begin{array}{l}0.7^{* *} \\
0.9^{* *}\end{array}$ \\
\hline Romania & $\begin{array}{l}2003 \\
2004+t \\
1999+t\end{array}$ & $\begin{array}{l}166,700 \\
134,100 \\
374,100\end{array}$ & $\begin{array}{l}35 \\
28 \neq \neq \\
74\end{array}$ & $\begin{array}{r}78 \\
64 \\
150\end{array}$ & $\begin{array}{l}1.0 \\
0.8 \\
2.2^{* *}\end{array}$ & Hong Kong & $\begin{array}{l}2003 \\
1996\end{array}$ & $\begin{array}{l}17,400 \\
25,000\end{array}$ & $\begin{array}{l}10 \\
15\end{array}$ & $\begin{array}{l}37 \\
40\end{array}$ & $\begin{array}{l}0.3 \\
0.5\end{array}$ \\
\hline Ukraine & $\begin{array}{l}2003 \\
1999+\dagger\end{array}$ & $\begin{array}{l}315,800 \\
589,200\end{array}$ & $\begin{array}{l}30 \\
54\end{array}$ & $\begin{array}{r}77 \\
110\end{array}$ & $\begin{array}{l}0.9^{* *} \\
1.6\end{array}$ & Japan & $\begin{array}{l}2003 \\
1996\end{array}$ & $\begin{array}{l}319,800 \\
338,900\end{array}$ & $\begin{array}{l}13 \\
13\end{array}$ & $\begin{array}{l}28 \\
28\end{array}$ & $\begin{array}{l}0.4 \\
0.4\end{array}$ \\
\hline Northern Europe & & & & & & Mongolia & 2003 & 10,500 & 16 & 18 & $0.5^{* *}$ \\
\hline Ireland§§ & 2003 & 6,300 & 7 & 10 & 0.2 & South Korea & $1999+\dagger$ & 212,300 & $26 \neq \ddagger$ & 38 & 0.7 \\
\hline Northern Ireland§§ & 2003 & 1,300 & 4 & 6 & 0.1 & $\begin{array}{l}\text { South/Southe } \\
\text { Bangladesh* }{ }^{*}\end{array}$ & $\begin{array}{l}\text { sia } \\
2000\end{array}$ & 119,600 & 4 & 3 & $0.1 * *$ \\
\hline $\begin{array}{l}\text { Southern Europe } \\
\text { Albania }\end{array}$ & 2003 & 6,900 & 9 & 15 & $0.3^{* *}$ & India & 2001 & 723,100 & 3 & 3 & $0.1^{* *}$ \\
\hline Croatia & 2003 & 5,900 & 7 & 15 & 0.2 & & $\begin{array}{l}1996 \\
2002+^{*}\end{array}$ & $\begin{array}{r}570,900 \\
2,400,000\end{array}$ & $\begin{array}{r}3 \\
10\end{array}$ & $\begin{array}{l}2 \\
9\end{array}$ & $\begin{array}{l}0.1^{* *} \\
0.3^{* *}\end{array}$ \\
\hline Macedonia & $2000^{*}+$ & 11,400 & 25 & 39 & $0.7^{* *}$ & Vietnam & $\begin{array}{l}2003 \\
1996\end{array}$ & $\begin{array}{r}540,400 \\
1,520,000\end{array}$ & $\begin{array}{l}26 \\
83\end{array}$ & $\begin{array}{l}33 \\
78\end{array}$ & $\begin{array}{l}0.8^{* *} \\
2.5^{* *}\end{array}$ \\
\hline $\begin{array}{l}\text { Serbia and } \\
\text { Montenegro }\end{array}$ & 2002 & 33,600 & 15 & $26^{*} \neq$ & $0.5^{* *}$ & & $\begin{array}{l}1996 \\
2002+\dagger \\
1997+\dagger\end{array}$ & $\begin{array}{r}1,520,000 \\
367,500 \\
325,100\end{array}$ & $\begin{array}{l}83 \\
20 \neq \neq \\
18 \neq \neq\end{array}$ & $\begin{array}{l}18 \\
22 \\
17\end{array}$ & $\begin{array}{l}2.5 n \\
0.6 \\
0.5\end{array}$ \\
\hline Spain & 2003 & 79,800 & 8 & 18 & $0.2^{* *}$ & Western Asia & & & & & \\
\hline $\begin{array}{l}\text { Central Asia } \\
\text { Kazakhstan }\end{array}$ & 2003 & 127,200 & 35 & 51 & $1.0^{* *}$ & Armenia & $\begin{array}{l}2003 \\
2000+\dagger\end{array}$ & $\begin{array}{r}7,800 \\
61,500\end{array}$ & $\begin{array}{l}10 \\
81\end{array}$ & $\begin{array}{r}22 \\
156\end{array}$ & $\begin{array}{l}0.3^{* *} \\
2.6^{* *}\end{array}$ \\
\hline & $1999+t$ & 176,100 & 47 & 76 & 1.4 & Azerbaijan & 2003 & 12,000 & 6 & 11 & $0.2^{* *}$ \\
\hline Kyrgyzstan & $\begin{array}{l}2003^{*}+ \\
1997+\dagger\end{array}$ & $\begin{array}{l}19,200 \\
54,300\end{array}$ & $\begin{array}{l}15 \neq \neq \\
51\end{array}$ & $\begin{array}{l}17 \\
27\end{array}$ & $\begin{array}{l}0.5^{* *} \\
1.5\end{array}$ & Georgia & $\begin{array}{l}2001+\dagger \\
2003^{*}+\end{array}$ & $\begin{array}{r}244,400 \\
13,800\end{array}$ & $\begin{array}{r}116 \\
14\end{array}$ & $\begin{array}{r}203 \\
30\end{array}$ & $\begin{array}{l}3.2 \\
0.4\end{array}$ \\
\hline Tajikistan & 2003 & 10,500 & 7 & 7 & $0.2^{* *}$ & & $\begin{array}{l}2005+t \\
1999+t\end{array}$ & $\begin{array}{l}103,700 \\
128,600\end{array}$ & $\begin{array}{l}103 \neq \neq \\
135\end{array}$ & $\begin{array}{l}224 \\
264\end{array}$ & $\begin{array}{l}3.1 \\
3.7\end{array}$ \\
\hline Turkmenistan & $2000+t$ & 28,500 & 26 & 27 & 0.9 & Turkey & $2003+t$ & 146,800 & $12 \neq \neq$ & 10†‡ & 0.4 \\
\hline Uzbekistan & $\begin{array}{l}2003 \\
2002+\dagger\end{array}$ & $\begin{array}{r}27,700 \\
166,200\end{array}$ & $\begin{array}{r}4 \\
28\end{array}$ & $\begin{array}{r}5 \\
28\end{array}$ & $\begin{array}{l}0.1^{* *} \\
0.9\end{array}$ & & $1998+\dagger$ & 270,600 & $18 \neq \ddagger$ & 19 & 0.4 \\
\hline $\begin{array}{l}\text { *Rounded to the neare } \\
\text { have during her reprod } \\
\text { t+Based on a nationally } \\
15-49 \text { ) and Turkey (eve } \\
\text { women aged } 20-44 \text {. D } \\
\text { ing five years) and in Uk } \\
\text { by multiplying the tota } \\
\text { spontaneous abortions } \\
\text { per } 100 \text { live births to all } \\
\text { Albania, China, Croatia, } \\
\text { cede survey-based esti }\end{array}$ & $\begin{array}{l}\text { luctive lifetir } \\
\text { y representa } \\
\text { ar-married w } \\
\text { ata reflect ay } \\
\text { kraine (prece } \\
\text { I abortion ra } \\
\text { s. * *Based o } \\
\text { women. No } \\
\text { Japan, Mac } \\
\text { mates wher }\end{array}$ & $\begin{array}{l}\text { ortions per } 1 \\
\text { ime, given pr } \\
\text { ative survey } \\
\text { Nomen aged } \\
\text { verage annu } \\
\text { eding one ye } \\
\text { ate by } 1,000 \\
\text { on live births } \\
\text { otes: Estimate } \\
\text { cedonia, Mol } \\
\text { re both are a }\end{array}$ & $\begin{array}{l}\text { ncid } \\
\text { Cot } \\
\text { div }\end{array}$ & $\begin{array}{l}\text { The estir } \\
\text { nce and } \\
\text { numbe } \\
\text { ing by } 3 \\
\text { sMenst } \\
\text { wn to b }\end{array}$ & $\begin{array}{l}15-44, \text { exc } \\
\text { ated num } \\
\text { tes for the } \\
\text { of abortion } \\
\S \S \text { Aborti } \\
\text { ual regulat } \\
\text { incomplet }\end{array}$ & $\begin{array}{l}\text { per } 100 \text { live birtt } \\
\text { stimated by divi } \\
\text { outh Korea (marr } \\
\text { ortions in South } \\
\text { ears preceding th } \\
\text { lculated from the } \\
\text { gland and Wales } \\
\text { ased on a survey } \\
\text { :ountries except } \\
\text { ia and Monteneg }\end{array}$ & $\begin{array}{l}\text { number } \\
\text { general } \\
\text { nen aged } \\
\text { ysumes } t \\
\text { on rate ar } \\
\text { ed by wor } \\
\text { Ith faciliti } \\
\text { in and for } \\
\text { in Taj }\end{array}$ & $\begin{array}{l}\text { r of abortions } \\
\text { labortion rate } \\
\text { d 20-44), Viet } \\
\text { that the rate } \\
\text { t in South Kor } \\
\text { ind may inclu } \\
\text { men who gav } \\
\text { :ies. . } ¥ \text { Abortic } \\
\text { rwhich the le } \\
\text { ijkistan. For e }\end{array}$ & $\begin{array}{l}\text { s that the } \\
\text { e by } 1,000 \\
\text { tnam (ever } \\
\text { for marrie } \\
\text { rea, Vietna } \\
\text { de illegal } \\
\text { ve Irish ad } \\
\text { ons obtain } \\
\text { vel of com } \\
\text { ach count }\end{array}$ & $\begin{array}{l}\text { average wo } \\
\text { and multip } \\
\text { r-married w } \\
\text { ed women a } \\
\text { am and Turl } \\
\text { abortions. } \\
\text { idresses. }{ }^{*+} \\
\text { ned by mar } \\
\text { npleteness } \\
\text { try, official s }\end{array}$ & $\begin{array}{l}\text { oman would } \\
\text { plying by } 30 . \\
\text { vomen aged } \\
\text { applies to all } \\
\text { key (preced- } \\
\text { \#+Estimated } \\
\text { - May include } \\
\text { ried women } \\
\text { is uncertain: } \\
\text { ttatistics pre- }\end{array}$ \\
\hline
\end{tabular}

15-44 were reported in official statistics for 2003, but the 2001 fertility survey estimated an annual rate of 116. * Official statistics are likely to also seriously undercount abortions in some countries with incomplete reporting but without survey data.

Abortion rates estimated from surveys of women in Armenia, Azerbaijan and Georgia (81, 116 and 103, respectively) were the highest rates recently reported for any country with complete or incomplete data. Women in these countries will have an average of three abortions each if cur-

*This is an annual rate, based on abortions reported in the three years preceding the survey. rent levels prevail throughout their reproductive lives. These persistently high rates are explained by small desired family size, early completion of childbearing and continued reliance on traditional methods of family planning, which have high failure rates. ${ }^{30}$ Use of modern contraceptives is low in these countries relative to use in other countries of the former Soviet Union. ${ }^{16}$

Abortion estimates are available for earlier years for Georgia, Romania and Turkey. According to reproductive health surveys in Romania, the abortion rate decreased by more than 60\% from 1999 to 2004, while the total fertility rate remained stable at about 1.3 births per woman. ${ }^{31}$ Although the downturn in abortion in these countries is generally as- 
sociated with increased contraceptive use, the rise in modern contraceptive use from 48\% to 58\% among Romanian women aged 15-44 is unlikely to fully account for a decline of this magnitude. ${ }^{31}$ An increase in the effectiveness of contraceptive use may partly explain the large decline in abortions, but data are not available to assess this hypothesis. Changes in the administration of the survey might have caused a decline in the completeness of abortion reporting over time. Furthermore, the reporting of abortion experiences in face-to-face interviews might have decreased if opinion regarding abortion has become more conservative.

Similarly, recent surveys indicated a modest increase in the use of modern contraceptives in Turkey between 1998 and 2003 , from $38 \%$ to $43 \%$ among ever-married women aged $15-44$, but this does not seem to account for the 31\% decrease in abortions among these women, particularly since the total fertility rate also decreased over this period, from 2.6 to 2.2. ${ }^{32}$ Informants have suggested that the effectiveness of method use, including the use of traditional methods, has increased over time. It is also possible that reporting has become less complete.

- Southern and Northern Europe. In Southern Europe, the official abortion rate was moderate in Macedonia (25 per 1,000 women) and low in Serbia and Montenegro (15) and Albania (nine). Local experts indicate that the true abortion level is much higher in Albania, and a 2002 survey showed that the use of traditional contraceptives prevails over modern method use. ${ }^{33}$ The low abortion rate in Croatia (seven) has been attributed to the influence of conservative forces, state efforts to restrict access to abortion and high fees for the procedure, in addition to incomplete reporting. ${ }^{34}$

Estimates of abortion rates for Ireland (seven) and Northern Ireland (four) were limited to data on women who obtained abortions in England and Wales and gave addresses in Ireland or Northern Ireland. They excluded Irish women who gave non-Irish addresses, those who had abortions in other countries and the probably small number of women who had legal abortions in Northern Ireland.

- South Asia. According to Ministry of Health official statistics, the legal abortion rate remained unchanged in India between 1996 and 2001 (three per 1,000), even though the absolute number of abortions increased dramatically during that time. Abortion is legal under broad grounds in India, but regulations require that they be performed by registered physicians in certified facilities, and official statistics include only procedures that meet these regulations. Because of the difficulties in meeting all official requirements, a large number of safe abortions by qualified physicians are not reported. ${ }^{35}$ It is also likely that some physicians who are certified to perform legal abortions do not report or underreport the number of procedures they perform. According to estimates using findings from a facility-based survey conducted in six states, ${ }^{35}$ about 2.4 million safe abortions are performed annually in India by formally trained providers in approved facilities, and the safe abortion rate is 10 per 1,000 women. However, the survey also estimated that nearly two-thirds of abortions are not performed at approved facilities, indicating that the overall abortion rate is about three times the safe abortion rate.

The abortion rate for Bangladesh was based on official statistics and included only menstrual regulation procedures, which are legally permitted. Surgical abortions past 10 weeks' gestation are prohibited under most conditions and are not registered. Menstrual regulation procedures are estimated to account for more than half of all abortions in Bangladesh, ${ }^{36}$ but most go unreported. ${ }^{37}$ Hence the official abortion rate of four per 1,000 women likely is an underestimate; the actual rate, including safe and unsafe abortions, was estimated to fall between 26 and 30 in $1995 .{ }^{36}$

- East and Southeast Asia. Abortion counts for China were obtained from the Ministry of Health. (In the past, abortion data were also collected by the Family Planning Commission; however, experts indicate that reliable estimates are no longer available from this source.) Medication abortions, which are estimated to account for up to a third of induced abortions in China, are missing from the abortion statistics for at least some provinces, and they may be missing from the national count altogether. Informants also indicated that some private clinics that do not have government permission to perform abortions do not report the abortions they perform, and some providers or districts might overreport abortions to meet quotas or obtain government compensation. The year-to-year fluctuations in the number of abortions reported (not shown) suggest that there is some error in the data.

Abortion incidence appears to have decreased in China, which accounted for more than a third of legal abortions worldwide in $1996 .{ }^{1}$ According to Ministry of Health reports, the rate declined by $21 \%$, from 29 to 23 per 1,000 women, between 1996 and 2003, though the fertility rate also declined slightly during this interval. ${ }^{38}$ Contraceptive prevalence was already high at the start of this period, yet contraceptive failure rates were also high, ${ }^{39}$ and $70 \%$ of abortions in China were attributed to contraceptive failure. ${ }^{40}$ The failure rate associated with the IUD-the most prevalent method in China-decreased significantly in the 1990s, when the copper IUD was introduced and began to replace less effective devices. ${ }^{40}$ Therefore, the abortion and fertility rates might have declined simultaneously. The decline in abortion incidence has also been linked to the Family Planning Commission's increased emphasis on quality of care in family planning services, including the expansion of contraceptive options, in the past decade. ${ }^{41}$ In addition, some research has indicated that greater use-effectiveness, stemming from the growing desire for small families and stronger motivation among couples to prevent births, could explain some of the decline in the abortion rate. ${ }^{42}$

According to official reports, more than half a million abortions were performed in Vietnam in 2003, and the abortion rate was 26 per 1,000 women. Official statistics show a $69 \%$ decline in the rate over seven years, from 83 in 1996. However, the total fertility rate declined from 2.7 to 1.9 births per woman, and contraceptive prevalence did not change substantially in that time. ${ }^{43}$ The total abortion rate among 
TABLE 3. Age-specific legal abortion rates, by country and year

\begin{tabular}{lccccccc} 
Country & Year & $\leq 19^{*}$ & $20-24$ & $25-29$ & $30-34$ & $35-39$ & $\geq 40$ \\
\hline Eastern Europe & & & & & & & \\
Czech Republic & 2003 & 8 & 14 & 15 & 16 & 13 & \\
& 1996 & 12 & 27 & 31 & 28 & 19 & 10 \\
Hungary & 2003 & 20 & 33 & 33 & 31 & 24 & \\
& 1996 & 30 & 47 & 49 & 44 & 31 & 13 \\
Russian Federation & 2003 & 25 & 69 & 70 & 58 & 38 & 15 \\
& 1996 & 44 & 144 & 145 & 94 & 55 & 3
\end{tabular}

Northern Europe

Denmark

England and Wales $¥ 2003$

Estonia 2003

1996

Finland

Latvia

Lithuania

Norway

Scotland

Sweden

Southern Europe

Italy

Slovenia

Western Europe

Belgium

Germany

Netherlands $\ddagger$

Canada

United States§

Oceania

New Zealand

2003

1996

27
22

Western Asia

Israel**

2003

1996

$\begin{array}{rrrrr}15 & 21 & 18 & 17 & 13 \\ 15 & 23 & 21 & 20 & 13 \\ & & & & \\ 23 & 31 & 22 & 15 & 10 \\ 22 & 28 & 20 & 14 & 9\end{array}$

$\begin{array}{llllll}28 & 53 & 51 & 43 & 32 & 14\end{array}$

$\begin{array}{llllll}43 & 93 & 83 & 63 & 43 & 19\end{array}$

$\begin{array}{llllll}15 & 17 & 12 & 11 & 8 & 3 \\ 11 & 15 & 14 & 11 & 7 & 3\end{array}$

$\begin{array}{llllll}17 & 42 & 42 & 37 & 26 & 11\end{array}$

$\begin{array}{llllll}7 & 21 & 23 & 21 & 15\end{array}$

$\begin{array}{llllll}16 & 27 & 19 & 15 & 11 & 4 \\ 16 & 26 & 21 & 16 & 10 & 4\end{array}$

$\begin{array}{llllll}20 & 23 & 15 & 9 & 5 & 2\end{array}$

$\begin{array}{llllll}18 & 21 & 14 & 9 & 5 & 2\end{array}$

$\begin{array}{llllll}25 & 31 & 24 & 21 & 16 & 7\end{array}$

$\begin{array}{lllllll}18 & 28 & 25 & 21 & 15 & 7\end{array}$

$\begin{array}{llllll}2003 & 7 & 15 & 14 & 12 & 10\end{array}$

2003

1996

$\begin{array}{rr}9 & 18 \\ 11 & 26\end{array}$

$\begin{array}{rrrr}21 & 21 & 19 & 9 \\ 28 & 32 & 27 & 15\end{array}$

1996

2003

1997

2003

1996

$\begin{array}{rrrrrr}8 & 13 & 11 & 9 & 6 & 2 \\ 7 & 11 & 10 & 8 & 5 & 2 \\ 7 & 13 & 11 & 9 & 6 & 3 \\ 6 & 11 & 11 & 9 & 7 & 3 \\ & & & & & 3 \\ 9 & 14 & 12 & 9 & 7 & 2\end{array}$

*Based on abortions obtained by women aged 19 or younger and the female population aged 15-19. + Based on abortions obtained by women aged 40 or older and the female population aged $40-44$. $\neq$ Residents only. $\S$ Based on total abortion incidence presented in Table 1 and age distributions reported to the U.S. Centers for Disease Control and Prevention. **Based on abortion applications approved, as reported to the Central Bureau of Statistics. ever-married women did not decrease according to the Demographic and Health Surveys of 1997 and 2002, although abortions were seriously underreported in those surveys. ${ }^{44}$ In Vietnam, the "semiprivate" sector, in which abortions are performed in public hospitals but not recorded, and the private sector, in which abortions are performed in private facilities, have grown in recent years. ${ }^{45,46}$ Abortions performed in these sectors are said to offer greater anonymity, better options for pain control and shorter waiting times. ${ }^{45}$ Because information for these sectors is unavailable, it is difficult to assess abortion levels or trends in Vietnam.

In South Korea, the survey-based abortion rate of 26 per 1,000 women is for married women only, and the estimated number of abortions assumes that this rate applies to unmarried women as well. Official statistics in Japan suggest an abortion rate of 13; however, some researchers have indicated that the actual rate is likely higher than reported. ${ }^{47}$ Higher rates are possible given that an estimated $60 \%$ of married couples use modern contraceptives, and $80 \%$ of these couples rely on condoms, which generally have a high use-failure rate. ${ }^{48,49}$ Trend data suggest, however, that the overall abortion level has been fairly stable since the early 1990s, following a long period of decline.

\section{Age-Specific Abortion Rates}

Age-specific abortion rates were calculated for 21 countries; for 18 of these, comparable rates could be estimated for 1996 and 2003 (Table 3).

In many countries, a general pattern emerged, in which the abortion rate was low for women younger than 20, peaked among those aged 20-24 and declined with each successive age-group. In Eastern Europe, abortion rates remained high for women aged 25-34 and descended more gradually with successive age-groups than rates in Western Europe and other developed countries. Survey findings for the Western and Central Asian countries, where abortion rates were among the highest in the world, show that rates tended to peak among women aged 25-34 (not shown). ${ }^{14}$ The age-specific abortion pattern in these regions reflects that many women have abortions to limit family size rather than to delay the start of childbearing. ${ }^{30}$

The abortion rate among 20-24-year-olds was higher in the United States than in other developed countries; however, U.S. rates among women aged 30 or older were lower than those in many developed countries. By 2003, the teenage abortion rate in the United States (22 per 1,000 women) was comparable to that in England and Wales (23) and Sweden (25). This situation marks a change from the mid-1990s, when this rate was substantially higher in the United States (29) than in these countries (22 and 18, respectively); the change is due in part to a decline in the adolescent abortion rate in the United States between 1996 and 2003. Over the same period, however, the adolescent abortion rate rose in Sweden-a trend that Swedish researchers attribute partly to cuts in funding for sex education and increases in the incidence of casual sex without contraceptive use. ${ }^{50}$ Nevertheless, the English-speaking de- 
veloped countries have higher adolescent abortion rates than many other developed countries, with the exception of the former Soviet states. This difference is ascribed to the more pragmatic approach to adolescent sexuality in other developed countries, including easier access to contraceptive services for adolescents. ${ }^{51-53}$

Trends in the abortion rate differed for various age-groups in some regions and countries. In the Netherlands, Finland and Sweden, rates increased by 33-65\% among women aged 19 or younger; the rate also increased by about $50 \%$ among 20-24-year-olds in the Netherlands. In Eastern Europe, where abortions were especially prevalent among women aged 20-34, rates decreased dramatically throughout this age span. In North America, the teenage abortion rate declined by $23 \%$ in both the United States and Canada between 1996 and 2003.

\section{DISCUSSION}

The prevalence of legal abortion varies widely across the countries in which it is generally available. Where the abortion rate is high, it likely reflects that levels of contraceptive use are not sufficient to meet the fertility desires and family planning needs of women and couples.

Many abortion rates in Eastern Europe and Western and Central Asia remain among the highest in the world. In Armenia, Azerbaijan, Georgia and the Russian Federation, more abortions than births still occur each year; this may also be the case in other countries of these regions with incomplete reporting. Abortion levels in Northern Europe and parts of Western Europe are among the lowest in countries with legal abortions. Abortion rates in the United States, while moderately low, are higher than rates in many developed countries outside of the former Soviet region, particularly among women younger than 30 .

Since 1996, more countries have experienced a decline in abortion rates than an increase, among those with complete abortion counts and trend data. The downward trend in reported legal abortions is most marked in Eastern Europe, and the incomplete statistics suggest that this trend was also strong in Central and Western Asia. The actual decrease in abortion rates is probably smaller than suggested by the data, because in these regions, abortions are increasingly being paid for privately (in either public or private facilities), and such procedures are less likely than others to be reported. These countries, along with Cuba, have a legacy of an "abortion culture" that characterized the Soviet era, when abortion was freely available but contraceptive options were limited and supplies not always available. ${ }^{54}$ In recent years, contraceptives have become more accessible and use has increased, though supplies and the range of methods available are often limited and the cost is sometimes high. Changes in contraceptive use have been slowest in Western Asian countries, where use of modern methods is lower than it is in most of the other former Soviet areas.

Abortion incidence is also reportedly declining in China. Possible causes of such a decline include more effective contraceptive use and improvements in the quality of family planning services. However, if medication abortions and abortions procured in the private sector are underreport$\mathrm{ed}$, and if increasing proportions of abortions fall in either or both of these categories, the actual decline could be smaller than the statistics suggest.

In Vietnam, reported abortion incidence was very high in the mid-1990s (83 abortions per 1,000 women), even though reporting was incomplete. The sharp decline in officially reported abortions since 1996 conflicts with the small increase in incidence suggested by nationally representative surveys in the same interval. The surveys, however, appear to greatly underestimate abortion levels. As a result, no conclusions can be drawn regarding current abortion incidence or recent trends.

The abortion rate increased, albeit modestly, in the Netherlands and New Zealand. Demand for abortion increased among residents of non-European descent in the Netherlands, which may reflect lower levels of contraceptive use among immigrant women. ${ }^{17}$ Similarly, the increase in abortions in New Zealand may be attributable to trends among women of Asian descent. ${ }^{22}$

Abortion rates have remained relatively stable in Northern and Western Europe. In most of these countries, abortion is available without restriction, and contraceptives are widely available at low cost and are considered acceptable to use. In North America, the abortion rate remained steady in Canada and declined by a little more than $1 \%$ annually in the United States.

Studies have demonstrated that abortion levels are strongly linked to contraceptive use patterns. ${ }^{15,16}$ The past few decades have been a significant period in the history of family planning, marked by improved contraceptive technology and growing and widespread acceptance of contraception throughout many regions of the world. It appears that where couples desire to limit their fertility and services are available, contraceptive use is eventually widely accepted. This phenomenon has been borne out in the former Soviet bloc during the past 15 years. In the United States, improvements in use have been shown to account for most of the decline in adolescent pregnancy rates in recent years. ${ }^{55}$

Where contraceptive use is widespread, unintended pregnancy and abortion rates will likely continue to decrease if the quality of contraceptive services improves and the effectiveness of use increases. This seems to be the case in China, where declines in abortion incidence coincided with increased use of a more effective IUD, and with other improvements in the quality of contraceptive services. Improvements in contraceptive technology could result in further reductions in abortion rates, even in countries where the most effective methods currently available are already widely used.

In societies or demographic subgroups in which contraceptives are not widely available or their use has not yet become a culturally accepted practice, but many women wish to avoid childbearing, abortions are likely to occur at higher-than-average levels. In traditional societies where

\section{Since 1996,}

more countries

\section{have experi-}

enced a decline

in abortion

rates than an

increase, among

those with com-

plete abortion

counts and

trend data. 
the age at marriage is increasing and sex before marriage is becoming more common, rates of unintended pregnancy and abortion could increase among young, unmarried women. Barriers to contraceptive use among unmarried women, including discomfort associated with seeking contraceptives, can exacerbate these circumstances. The European experience, however, demonstrates that societal acceptance of adolescent sexual relationships, combined with comprehensive information about contraceptives, can result in low pregnancy rates among young adults. ${ }^{53}$

In developed countries where contraception is accepted socially and family planning services are generally available, the abortion rate ranges from about seven to 20 per 1,000 women. In some subpopulations, the rate has been as low as 3-4 per 1,000, as among the Dutch-born population of the Netherlands in the recent past. ${ }^{56}$ Evidence suggests, however, that unwanted pregnancies and induced abortions occur to some degree in every society, for a number of reasons-contraceptive methods fail on occasion, couples do not always use their methods correctly or consistently, some women have partners who oppose contraceptive use, some become pregnant as a result of coerced sex and some seek abortion for health reasons or because of changes in their circumstances.

Unwanted pregnancies cannot be entirely avoided, but their incidence can be reduced through various means, such as improvements in the social acceptability of and access to contraception, the development of new contraceptive technologies, education and counseling to reduce partner violence and increase self-efficacy in contraceptive choice for women, and service improvements that facilitate continuous and effective contraceptive use.

Research on the association between abortion trends and trends in unmet need for contraception, availability of family planning services, desired family size and fertility rates can provide further evidence of how these factors may influence abortion levels at the regional and national levels, as well as among subgroups in each country.

\section{REFERENCES}

1. Henshaw SK, Singh S and Haas T, The incidence of abortion worldwide, International Family Planning Perspectives, 1999, 25(Suppl.):S30S38.

2. Henshaw SK, Singh S and Haas T, Recent trends in abortion rates worldwide, International Family Planning Perspectives, 1999, 25(1):44-48.

3. Council of Europe, Recent Demographic Developments in Europe 2004, Strasbourg, France: Council of Europe Publishing, 2005.

4. World Health Organization (WHO) Regional Office for Europe, European Health for All Database (HFA-DB), updated June 2006, $<$ http://www.euro.who.int/hfadb>, accessed June 1, 2006.

5. Rossier C, Estimating induced abortion rates: a review, Studies in Family Planning, 2003, 34(2):87-102.

6. Singh S, Henshaw SK and Berentsen K, Abortion: a worldwide overview, in: Basu AM, ed., The Sociocultural and Political Aspects of Abortion, Westport, CT, USA: Praeger Publishers, 2003, pp. 15-47.

7. Henshaw SK and Vargas YA, Study of induced abortion in Puerto Rico, 2001-2002, paper presented at Saludpromujer Seminario Actualidad del Aborto en Puerto Rico y el Mundo: Hallazgos de la Segunda Encuesta Nacional de Aborto, San Juan, Puerto Rico, Jan. 22, 2003.
8. Finer LB and Henshaw SK, Abortion incidence and services in the United States in 2000, Perspectives on Sexual and Reproductive Health, 2003, 35(1):6-15

9. Finer LB and Henshaw SK, Estimates of U.S. abortion incidence, 2001-2003, Guttmacher Institute, 2006, <http://www.guttmacher.org/ pubs/006/08/03/ab_incidence.pdf>, accessed Oct. 2, 2006.

10. Chan A and Sage LC, Estimating Australia's abortion rates 1985-2003, Medical Journal of Australia, 2005, 182(9):447-452

11. L'Union Suisse pour Décriminaliser l'Avortement, 2003, Interruptions de grossesse 2003, <http://www.svss-uspda.ch/pdf/IVG-Stat-details2003.pdf>, accessed Oct. 11, 2006

12. Jones RK, Darroch JE and Henshaw SK, Patterns in the socioeconomic characteristics of women obtaining abortions in 2000-2001, Perspectives on Sexual and Reproductive Health, 2002, 34(5):226-235.

13. International Planned Parenthood Federation (IPPF) European Network, Abortion Legislation in Europe, Brussels, Belgium: IPPF European Network, 2004.

14. U.S. Centers for Disease Control and Prevention (CDC) and ORC Macro, Reproductive, Maternal and Child Health in Eastern Europe and Eurasia: A Comparative Report (Revised 2005), Atlanta, GA, USA: CDC; and Calverton, MD, USA: ORC Macro, 2003, p. 39.

15. Marston C and Cleland J, Relationships between contraception and abortion: a review of the evidence, International Family Planning Perspectives, 2003, 29(1):6-13.

16. Westoff CF, Recent Trends in Abortion and Contraception in 12 Countries, DHS Analytical Studies, Princeton, NJ, USA: Office of Population Research, Princeton University; and Calverton, MD, USA: ORC Macro, 2005, No. 8.

17. Netherlands Ministry of Foreign Affairs, Questions and answers on Dutch policy on abortion, 2003, <http://www.minbuza.nl/ default.asp?CMS_TCP=tcpAsset\&id=2AlE1DEDB75F46DCAC9A0520 4E4C19C0X1X53953X18>, accessed Apr. 13, 2006.

18. Wijsen C and van Lee L, Abortion Registry 2004, Utrecht, Netherlands: Rutgers Nisso Groep, 2005 (in Dutch)

19. Bracken $\mathrm{H}$ and Winikoff B, The state of medical abortion in Europe today, Entre Nous, 2005, 59:7-10.

20. Spinelli A and Grandolfo M, Abortion in Italy, National Epidemiologic Bulletin, 2001, Vol. 14, No. 4, <http://www.epicentro.iss.it/ben/ precedenti/aprile/1_en.htm>, accessed Aug. 16, 2007.

21. Italian Ministry of Health, La salute in alcuni gruppi di popolazione, in: La Situazione Sanitaria del Paese, no date, <http://www. ministerosalute.it/imgs/C_17_pubblicazioni_506_ulterioriallegati_ ulterioreallegato_0_alleg.pdf>, accessed Apr. 5, 2007.

22. Goodyear-Smith F and Arroll B, Contraception before and after termination of pregnancy: can we do it better? New Zealand Medical Journal, 2003, Vol. 116, No. 1186, <http://www.nzma.org.nz/journal/1161186/683/content.pdf>, accessed Aug. 7, 2007.

23. Pan American Health Organization, Health in the Americas-1988 Edition, Vol. II, Washington, DC: Pan American Health Organization, 1998, pp. 206-219

24. Bensyl DM et al., Contraceptive use-United States and territories, Behavioral Risk Factor Surveillance System, 2002, Morbidity and Mortality Weekly Report, 2005, Vol. 54, No. SS-6.

25. Remez L, Puerto Rico: contraceptive use is high, sterilization is the most popular method, Family Planning Perspectives, 1999, 31(1):47-48.

26. Mtiraoui A and Gueddana N, The family and reproductive health program in underprivileged areas in Tunisia, paper presented at the CICRED Seminar on Reproductive Health, Unmet Needs and Poverty, Bangkok, Nov. 25-29, 2002

27. Jewkes RK et al., Why are women still aborting outside designated facilities in metropolitan South Africa? British Journal of Obstetrics and Gynaecology, 112(9):1236-1242

28. Ahman E and Shah IH, Unsafe Abortion: Global and Regional Estimates of the Incidence of Unsafe Abortion and Associated Mortality in 2000, fourth ed., Geneva: WHO, 2004. 
29. Dickson KE et al., Abortion service provision in South Africa three years after liberalization of the law, Studies in Family Planning, 2003, 34(4):277-284

30. Goldberg H and Serbanescu F, Induced abortion in the Caucasus republics: a detailed analysis, paper presented at the International Union for the Scientific Study of Population (IUSSP) XXV International Population Conference, Tours, France, July 18-23, 2005.

31. Romania Ministry of Health, World Bank, United Nations Population Fund, U.S. Agency for International Development and UNICEF, Reproductive Health Survey Romania, 2004 Summary Report, Bucharest, Romania: Romania Ministry of Health, 2005.

32. Institute of Population Studies, Turkey Demographic and Health Survey, 2003, Ankara, Turkey: Institute of Population Studies, Haceteppe University, 2004.

33. Morris L et al., Reproductive Health Survey Albania, 2002 Final Report, Tirana, Albania: Albania Ministry of Health; and Atlanta, GA, USA: CDC, U.S. Agency for International Development, United Nations Population Fund and UNICEF, 2005.

34. Cesar S, Reproductive health services in Croatia: country report, ASTRA-Central and Eastern European Women's Network for Sexual and Reproductive Health and Rights, 2005, <http://www.astra.org.pl/ articles.php?id=65>, accessed Aug. 12, 2007.

35. Duggal R and Ramachandran V, Summary and Key Findings, Abortion Assessment Project India, Mumbai, India: Center for Enquiry into Health and Allied Themes and Healthwatch, 2004.

36. Singh S et al., Estimating the level of abortion in the Philippines and Bangladesh, International Family Planning Perspectives, 1997, 23(3): 100-107 \& 144 .

37. Begum SF, Kamal H and Kamal GM, Evaluation of MR Services in Bangladesh, Dhaka, Bangladesh: Bangladesh Association for Prevention of Septic Abortion, 1987, pp. 1-2 \& 11.

38. U.S. Bureau of the Census, International Data Base, Country summary: China, 2007, <http://www.census.gov/ipc/www/idb/ country/chportal.html>, accessed Aug. 12, 2007.

39. Wang D, Contraceptive failure in China, Contraception, 2002 , 66(3):173-178.

40. Wang D and Altmann DR, Socio-demographic determinants of intrauterine device use and failure in China, Human Reproduction, 2002, 17(5):1226-1232.

41. Kaufman J, Erli Z and Zhenming X, Quality of care in China: from pilot project to national program, paper presented at the IUSSP XXV International Population Conference, Tours, France, July 18-23, 2005.

42. Giovanna MM, Has the Chinese family planning program been successful in changing fertility preferences? Demography, 2002, 39(3):557-572.

43. Committee for Population, Family and Children (Vietnam) and ORC Macro, Vietnam Demographic and Health Survey, 2002, Calverton, MD, USA: Committee for Population, Family and Children and ORC Macro, 2003.

44. Nguyen TNH, The role of family planning and abortion in fertility reduction in Vietnam, Mumbai, India: International Institute for Population Sciences, 2005.

45. WHO, Abortion in Viet Nam: An Assessment of Policy, Programme and Research Issues, Geneva: WHO, 1999.

46. Nghia DT and Khe ND, Vietnam abortion situation country report, paper presented at Expanding Access: Advancing the Roles of Midlevel Providers in Menstrual Regulation and Elective Abortion Care, Pilanesberg National Park, South Africa, Dec. 2-6, 2001.

47. Sato R, Contraceptive use and induced abortion in Japan-how is it so unique among the developed countries? paper presented at the IUSSP XXV International Population Conference, Tours, France, July 18-23, 2005.

48. Ali MM, Cleland J and Shah IH, Condom use within marriage: a neglected HIV intervention, Bulletin of the World Health Organization, 2004, 82(3):180-186.

49. Ranjit $\mathrm{N}$ et al., Contraceptive failure in the first two years of use: differences across socioeconomic subgroups, Family Planning Perspectives, 2001, 33(1):19-27.

50. Edgardh K, Department of Obstetrics and Gynecology, Karolinska University Hospital-Solna, Stockholm, Sweden, personal communication, Feb. 8, 2007.

51. Furstenberg FF, Jr., When will teenage childbearing become a problem? the implications of Western experience for developing countries, Studies in Family Planning, 1998, 29(2):246-253.

52. Santow $G$ and Bracher M, Explaining trends in teenage childbearing in Sweden, Studies in Family Planning, 1999, 30(3):169-182.

53. Singh S and Darroch JE, Adolescent pregnancy and childbearing: levels and trends in developed countries, Family Planning Perspectives, 2000, 32(1):14-23.

54. Agadjanian V, Is "abortion culture" fading in the former Soviet Union? views about abortion and contraception in Kazakhstan, Studies in Family Planning, 2002, 33(3):237-248.

55. Santelli JS et al., Explaining recent declines in adolescent pregnancy in the United States: the contribution of abstinence and improved contraceptive use, American Journal of Public Health, 2007, 97(1):150-156.

56. Rademakers J, Abortion in the Netherlands 1991-1992, Utrecht, Netherlands: Stimezo Nederland, 1995, p. 32, Table 1.12 (in Dutch).

\section{RESUMEN}

Contexto: La información sobre los niveles y tendencias de aborto pueden sustentar investigaciones y politicas que afectan la salud materna y reproductiva, pero la incidencia del aborto legal no ha sido evaluada en cerca de una década.

Métodos: Se realizó una compilación de estadísticas sobre abortos legales en 2003 para 60 países en los que el procedimiento es legal en términos generales; $y$, cuando fue posible, las tendencias fueron evaluadas. Las fuentes de datos incluyeron informes publicados y no publicados generados por sistemas oficiales de información nacional, cuestionarios enviados a agencias gubernamentales y encuestas de población representativas a nivel nacional. Funcionarios involucrados en la recolección de datos y expertos nacionales y regionales evaluaron qué tan completas eran las estimaciones para cada país.

Resultados: En años recientes, en los países para los que las estadísticas están completas y hay disponibilidad de datos sobre tendencias, se registró que hubo más países que experimentaron una disminución que un aumento en las tasas de aborto legal. Las disminuciones más dramáticas ocurrieron en Europa Oriental y Asia Central, en donde, sin embargo, las tasas permanecen entre las más altas del mundo. Los niveles estimados más altos se encontraron en Armenia, Azerbaiyán y Georgia, en donde las encuestas indican que, en promedio y a lo largo de su vida, cada mujer tendrá cerca de tres abortos. La tasa de aborto en los EE.UU. disminuyó en $8 \%$ entre 1996 y 2003, pero continúan siendo más alta que las tasas observadas en muchos países de Europa del Norte y Occidental. Las tasas aumentaron en los Países Bajos y Nueva Zelandia. En China, país que representó un tercio de los abortos legales del mundo en 1996, la tasa de aborto oficial disminuyó en $21 \%$ a lo largo de siete años. En algunos países, las tendencias en las tasas de aborto difirieron entre los grupos de edad.

Conclusiones: La tasa de aborto varía ampliamente entre los países en los que el aborto legal está disponible en términos generales y ha disminuido en muchos países desde mediados de los años noventa. 


\section{RÉSUMÉ}

Contexte: L'information relative aux taux et tendances de l'IVG peut être utile à la recherche et aux politiques de santé maternelle et génésique, mais l'incidence de l'avortement légal n'a pas été évaluée depuis près de 10 ans.

Méthodes: Les statistiques relatives aux IVG pratiquées légalement en 2003 ont été compilées pour 60 pays dans lesquels la procédure est largement admise et les tendances ont été évaluées dans la mesure du possible. Les données de l'étude proviennent des rapports publiés ou non de systèmes statistiques officiels nationaux, de questionnaires adressés aux autorités gouvernementales et d'enquêtes démographiques nationalement représentatives. Les responsables de la collecte des données et des experts nationaux et régionaux ont évalué la complétude des estimations des différents pays.

Résultats: Ces dernières années, parmi les pays pour lesquels les statistiques sont complètes et des données de tendance sont disponibles, on enregistre plus souvent une baisse plutôt qu'une hausse des taux d'IVG légaux. Les régressions les plus spectaculaires ont été observées en Europe de l'Est et en Asie centrale, où les taux demeurent parmi les plus élevés du monde. Les plus hauts taux estimés concernent l'Arménie, l'Azerbaïdjan et la
Géorgie, où les enquêtes révèlent, en moyenne, trois IVG durant la vie de chaque femme. Aux États-Unis, le taux d'IVG s'est réduit de 8\% entre 1996 et 2003, mais il demeure supérieur à celui de nombreux pays d'Europe du Nord et de l'Ouest. Les taux sont en hausse aux Pays-Bas et en Nouvelle-Zélande. Le taux d'IVG officiel a baissé de 21\% sur une période de sept ans en Chine, qui représentait un tiers des avortements légaux pratiqués dans le monde en 1996. Les tendances des taux d'IVG diffèrent d'un groupe d'âge à l'autre dans certains pays.

Conclusions: Les taux d'IVG varient largement parmi les pays où l'avortement légal est généralement accessible. Ils sont en baisse, depuis la moitié des années 1990, dans de nombreux pays.

\section{Acknowledgments}

The authors thank Evert Ketting for his role in obtaining data, providing technical assistance with assessments of data quality and reviewing drafts of this article; and Erin Carbone for her assistance with data collection and management. Funding for this research was provided by the World Health Organization and the World Bank.

Author contact: gsedgh@guttmacher.org

\section{EXPANDED VERSION}

\section{International Family Planning Perspectives on CD}

\section{Access 15 years of peer-reviewed research on} sexual and reproductive health, originally published in International Family Planning Perspectives, from your computer desktop. The IFPP CD, expanded and reissued in August 2006, contains more than 1,000 searchable, printable PDF files from issues published between 1990 and 2004.

To receive your free $C D$, please fill out a request form at www.guttmacher.org/cd_rom/index.html.

To receive the request form, please email us at buyit@guttmacher.org, or write to us at: Guttmacher Institute 125 Maiden Lane, NY, NY 10038, EEUU

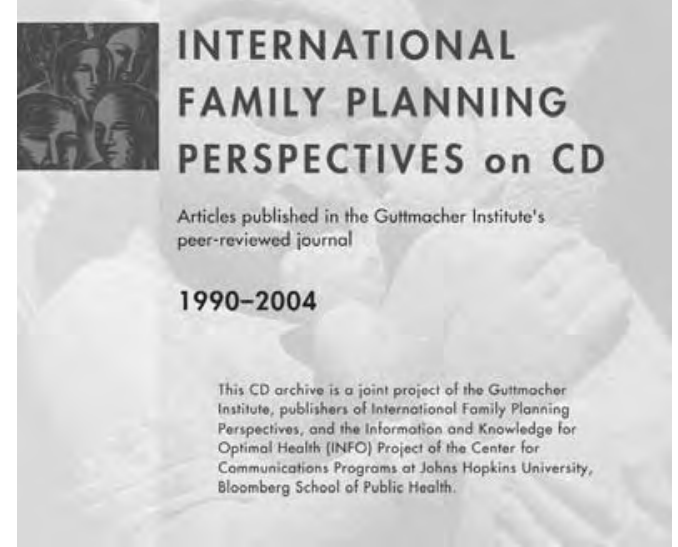

